\title{
Insight into the geology of the East Antarctic hinterland: a study of sediment inclusions from ice cores of the Lake Vostok borehole
}

\author{
G. L. Leitchenkov, ${ }^{1}$ B. V. Belyatsky, ${ }^{1}$ N. V. Rodionov, ${ }^{4}$ and S. A. Sergeev ${ }^{2}$ \\ ${ }^{1}$ Institute for Geology and Mineral Resources of the World Ocean (VNIIOkeangeologia), 1, Angliysky Ave. 190121, St.-Petersburg, Russia \\ (german_1@mail.ru) \\ ${ }^{2}$ All-Russian Geological Institute (VSEGEI), Center of Isotopic Research (CIR),74, Sredniy Ave, 199026, St.-Petersburg, Russia
}

\begin{abstract}
The borehole at the southern part of subglacial Lake Vostok has been drilled into an ice layer that has been refrozen from the lake water. This ice layer contains random sediment inclusions, eight of which have been studied using state-of the-art analytical techniques. Six inclusions comprise soft aggregates consisting mainly of clay-mica minerals and micron-sized quartz grains while two others are solid clasts of fine-grained cemented rocks. The largest rock clast consists of poorly-rounded quartz and minor amounts of accessory minerals and is classified as quartzose siltstone. More than twenty grains of zircon and monazite have been identified in this siltstone and dated by SIMS SHRIMP-II. Two age clusters have been recognized for these detrital grains, in the ranges 0.8-1.2 Ga and 1.6-1.8 Ga. The compositions of the rock clasts suggest that the bedrock situated to the west of Lake Vostok is sedimentary. The age data on the detrital accessory minerals suggest that the provenance of these sedimentary rocks - the Gamburtsev Mountains and Vostok Subglacial Highlands, is mainly represented by Paleoproterozoic and Mesoproterozoic-

Neoproterozoic crustal provinces.
\end{abstract}

Citation: Leitchenkov G.L., B.V. Belyatsky, N.V. Rodionov and S.A.and Sergeev (2007), Insight into the geology of the East Antarctic hinterland: study of sediment inclusions from ice cores of the Lake Vostok borehole, in Antarctica: A Keystone in a Changing World - Online Proceedings of the 10th ISAES, edited by A. K. Cooper and C. R. Raymond et al., USGS Open-File Report 2007-1047, Short Research Paper 014, 4 p.; doi:10.3133/of2007-1047.srp014.

\section{Introduction}

As more than $98 \%$ of East Antarctica (EA) is covered by a thick (up to $4 \mathrm{~km}$ ) ice sheet its geological and tectonic structure is deciphered mainly by study of rare outcrops located along the coastal areas. Exposed rocks compose complexes within a Precambrian Shield which includes: 1) ancient continental nuclei made up by Archaean (3.2-2.5 Ga) and Paleoproterozoic (2.4-1.6 Ga) cratons; 2) Mesoproterozoic-Neoproterozoic mobile belts (1.3-0.9 Ga) and 3) Late Neoproterozoic-Early Paleozoic $(0.6-0.48 \mathrm{Ga})$ assemblages which formed during the final stage of Gondwana amalgamation (Fitzsimons, 2000; Fig. 1). Between 0.55 and $0.48 \mathrm{Ga}$ the Pacific-facing edge of EA was evolved as an active margin with formation of subduction-related complexes of the Transantarctic Mountains (Fig. 1).

The first opportunity to obtain direct information about the bedrock geology of the central EA arose when the $3650 \mathrm{~m}$ deep borehole at the Vostok station, located in the southern part of Lake Vostok (largest subglacial freshwater lake in Antarctica; Kapitsa et al., 1996; Fig. 1 and 2) recovered the basal layer of the ice sheet. This layer contains rare sediment inclusions of up to few millimeters in size which have been derived from the lake bottom (Jousel et al., 1999). This paper presents results of studies conducted on the inclusions extracted from ice cores by: optic microscopy (VNIIOkeangeologia), X-ray diffractometry (St.-Petersburg State University), electron microscopy and SIMS SHRIMP-II dating (CIR VSEGEI).

Apart from the southern Prince Charles Mountains region, the geology of the EA hinterland remains absolutely unknown. However, it is proposed that subglacial highlands elevated well above sea level (up to more than $500 \mathrm{~m}$ ) are underlain mostly by basement assemblages of the Precambrian Shield whereas the EA lowlands located mainly to the west of the Transantarctic Mountains and in Wilkes Land are covered by Phanerozoic sedimentary (platform) strata (Fig. 1; Grikurov, 1980).

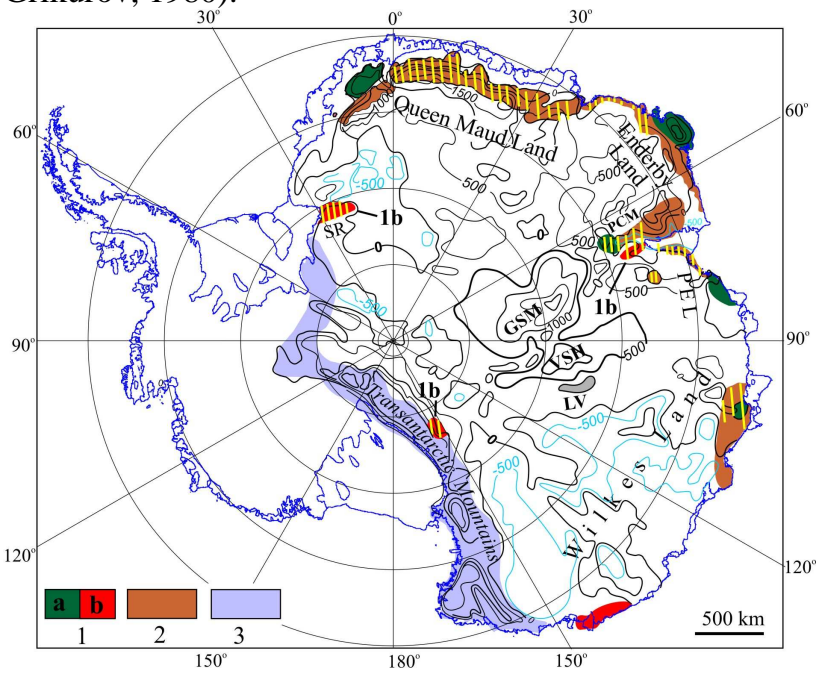

Figure 1. Major tectonic provinces of East Antarctica (modified from Grikurov et al., 2003). 1) Ancient cratons: a - Archaean (3.2-2.5 Ga), b - Paleoproterozoic (2.4-1.6 $\mathrm{Ga})$; 2) Mesoproterozoic-Neoproterozoic Mobile Belts (1.3-0.9 Ga); 3) Late Neoproterozoic-Early Paleozoic (Ross) Fold System (600-480 Ma). Yellow hatching shows areas affected by Late Neoproterozoic-Early Paleozoic tectonic event (0.7-0.5 Ga). Abbreviations: GSM - Gamburtsev Subglacial Mountains, LV - Lake Vostok, PCM - Prince Charles Mountains, PEL - Princess Elizabeth Land, SR - Shackleton Range, VSH - Vostok Subglacial Highlands. Bedrock topography is from Lythe et al. (2000). 


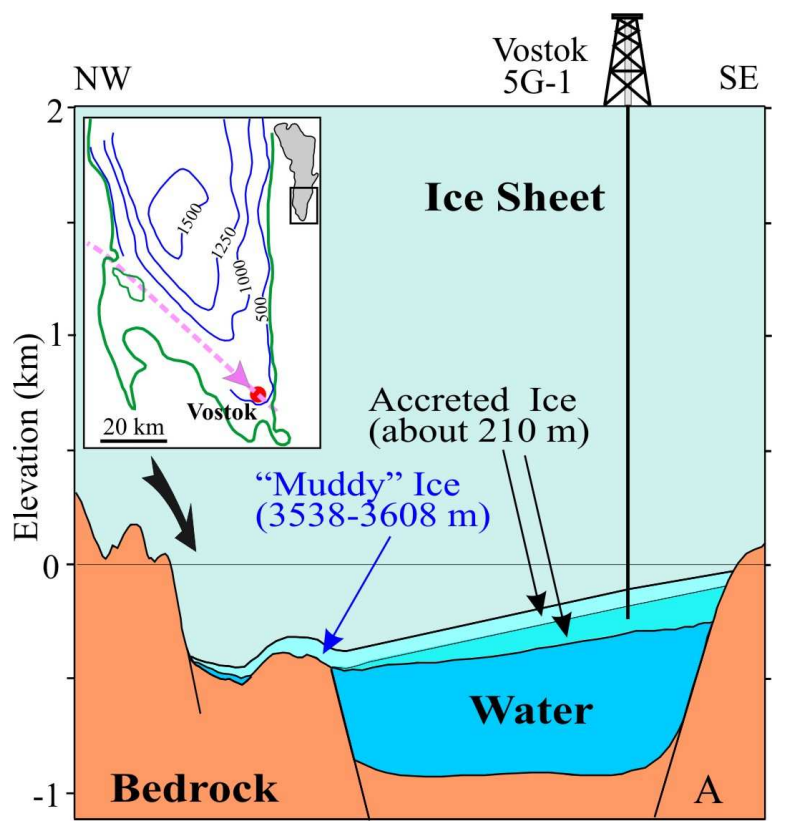

Figure 2. Section of ice sheet, water layer and bedrock along the ice flow line based on radio-echo sounding and seismic data acquired by the Russian Antarctic Expedition. Inset: Grounding line (green) and generalized bathymetry of southern Lake Vostok (modified from Leitchenkov et al., 2004). Dotted pink line with arrow shows direction of ice flow.

\section{Sediment inclusions}

According to drilling data as well as radio-echo sounding and seismic measurements, the ice layer containing inclusions (referred to as "muddy" ice) is the upper $70 \mathrm{~m}$ part of the $210 \mathrm{~m}$ thick accreted ice originating from refreezing of the lake water. In contrast the overlying $3538 \mathrm{~m}$ thick ice is meteoric and from precipitation in origin (Fig. 2). Below $3608 \mathrm{~m}$ and probably down to the ice-water interface, the accreted ice does not contain any visible sediment inclusions. Most of inclusions in muddy ice cores are dark (sometime brownish) formless clots up to few millimeters in size (Fig. 3). Their number is uneven, ranging from 5 to 30 per meter of core (Jouzel et al., 1999).

Radio-echo sounding and seismic data obtained during the last 10 years by the Russian Antarctic Expedition in the area of Lake Vostok (Leitchenkov et al., 2004; Popov, personal communication) show that the ice sheet recovered at the Vostok station flows from the southwestern ragged lake shore across the shallow lake bottom to the deep water (Fig. 2). Inclusions were entrapped from bottom sediments in the shallow area of the lake and incorporated into the accreted ice whereas the deeper clear ice was refrozen from the deep water. This interpretation is supported by the relationship between the length of the shallow area, exactly one third of the total ice flow distance from the lake edge to the borehole, and the thickness of the muddy ice, which is one third of the accreted ice thickness (Fig. 2). The bottom sediments are thought to be mostly erosional products of the bedrock upstream (to the west) from Lake Vostok and so provide evidence as to its composition (Fig. 2).

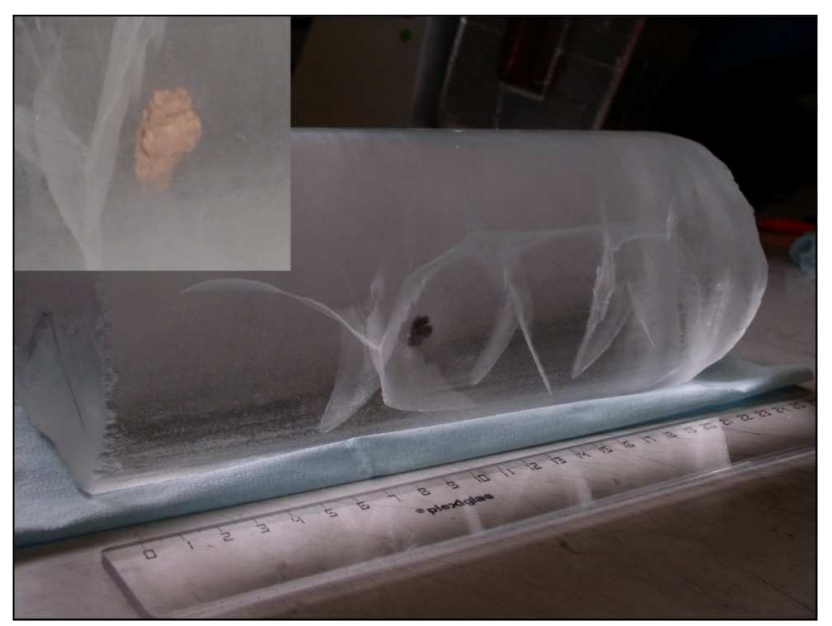

Figure 3. Core of accreted ice with sediment inclusion (soft aggregate). Photo by V. Lipenkov

Eight relatively large inclusions extracted from cores of the muddy accreted ice have been studied using different analytical equipment. Six of them (from depths of 3548, 3550, 3556, 3559, 3561, $3607 \mathrm{~m}$ ) were represented by soft aggregates which partially disintegrated after melting of the ice samples. The inclusions are soft aggregates, except for two from 3582 $\mathrm{m}$ and $3607 \mathrm{~m}$ depths, which are solid subangular to semirounded rock clasts 0.3 to $4.5 \mathrm{~mm}$ in size (Fig. 4).

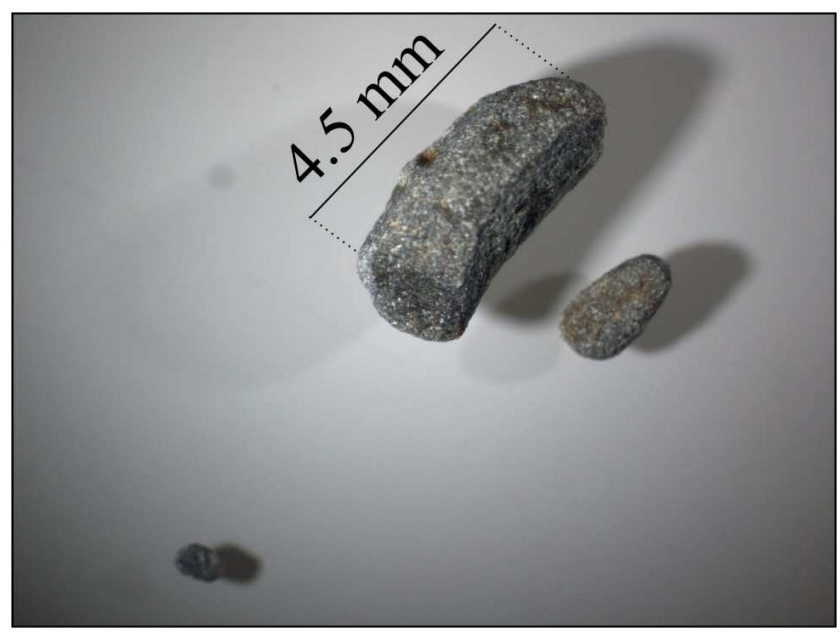

Figure 4. View of two large rock clasts from $3607 \mathrm{~m}$ depth.

Studies of manually disintegrated soft aggregates by optical microscope $(3550 \mathrm{~m}, 3556 \mathrm{~m}$ and $3561 \mathrm{~m}$ depth) and scanning electron microscope $(3548 \mathrm{~m}, 3559 \mathrm{~m}$ and $3607 \mathrm{~m}$ ) showed a predominance of clay minerals (less than $0.5 \mu \mathrm{m}$ in size; $30-60 \%$ of the total mineral content), 
quartz of subangular to angular shapes (ranging mainly between 10 and $40 \mu \mathrm{m}$ but amounting to $100 \mu \mathrm{m}$ in size; $30-60 \%$ ) and micas (up to $25 \mu \mathrm{m}$ in size; only muscovite was reliably identified). A variety of accessory minerals were also recorded (rutile, ilmenite, apatite, monazite, zircon, hornblende, feldspar, garnet, molybdenite, pyrite, sphalerite, ferric oxy-hydroxides and some other, generally from 5 to $40 \mu \mathrm{m}$ in size; less than $2 \%$ ). X-ray diffractometry ascertained that in the aggregate from 3607 $\mathrm{m}$ depth clay minerals are presented by illite and chlorite (clinochlore and chamosite). In the aggregate from 3548 $\mathrm{m}$ depth, a detrital zircon grain $40 \mu \mathrm{m}$ long and about 20 $\mu \mathrm{m}$ wide has also been identified (Leitchenkov et al., 2004).

After preparation of thin sections, solid inclusions from $3582 \mathrm{~m}$ and $3607 \mathrm{~m}$ depths were examined under an optical microscope and scanning electron microscope with X-ray detector to determine their nature and composition. The study showed that these inclusions are clasts of fine-grained cemented rocks. The two largest clasts (c. $4.7 \times 2.3 \times 2.2$ and $2.4 \times 1.4 \times 1.4 \mathrm{~mm}$ in size) from $3607 \mathrm{~m}$ depth were studied in more detail. They consist mainly (about $80 \%$ ) of poorly-rounded quartz (20-30 $\mu \mathrm{m}$ in size) and minor amounts of other minerals (orthoclase, rutile, apatite, zircon, monazite, garnet, magnetite) up to $30-40 \mu \mathrm{m}$ in size (Fig. 5). The rock cement is poorly studied but in some cases can be identified as argillaceous and siliceous material. By composition and grain size, the largest rock clasts can be identified as quartzose siltstone.

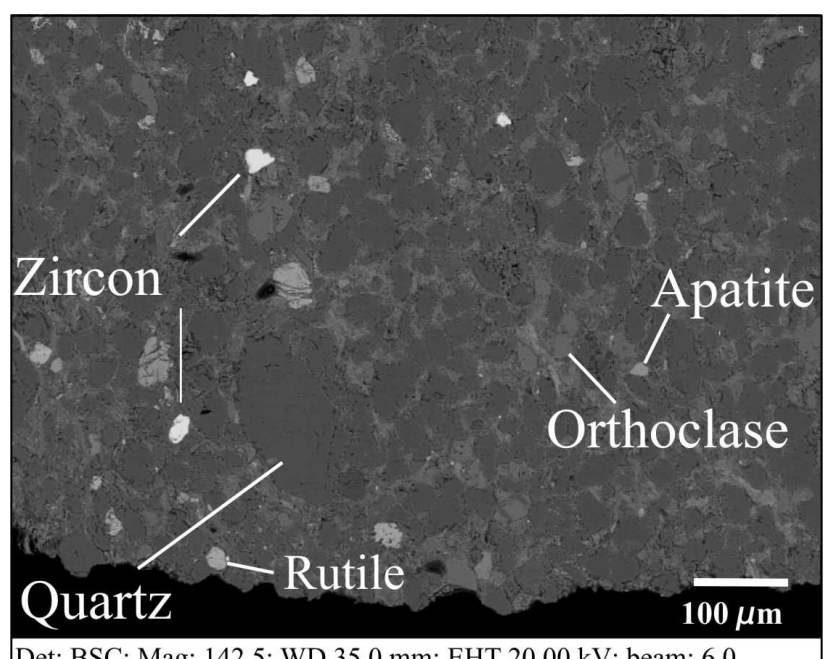

Det: BSC; Mag: 142.5; WD 35.0 mm; EHT $20.00 \mathrm{kV}$; beam: 6.0

Figure 5. Back-scatter electron image of rock clast from $3607 \mathrm{~m}$ depth with some identified minerals. Dark gray minerals are detritus quartz.

The thin section of the largest rock clast was studied using backscatter images to find accessory minerals. Among those, abundance of detrital zircons and monazites ranging in size from 2-5 to $30-40 \mu \mathrm{m}$ has been identified by X-ray imaging (Fig.5). 16 zircon and 5 monazite grains up to $20 \mu \mathrm{m}$ in size have been dated by SIMS SHRIMP-II directly from the thin section (Fig. 5). Some isotopic ratios showed relatively large errors which were caused by the small sizes of detrital minerals and incorporation of lead isotopes from the ambient mineral matter, but nevertheless age determinations appear to be statistically convincing and informative. The ages of the studied zircons range between 0.6 and $1.8 \mathrm{Ga}$ with two distinct peaks between 0.8 and $1.2 \mathrm{Ga}$ and 1.6 and $1.8 \mathrm{Ga}$ (Fig. 5). Monazites are low-uranium and their $\mathrm{Th}-\mathrm{Pb}$ ages $(0.8,1.0,1.5 \mathrm{Ga})$ are different from those obtained for (magmatic) zircons, perhaps because monazite crystallization is regarded as indicating metamorphic events.

\section{Data interpretation and discussion}

It is presumed that most of microparticles composing soft aggregates could be incorporated into refrozen lake water either from suspension by slow geothermally-driven upward water flow convection (Royston-Bishop et al., 2005) or by scavenging from the bottom with anchor ice and/or from water column with frazil ice crystals (Souchez et al., 2003). In the accreted ice microparticles coagulated into aggregates due to progressive water refreezing. Thus, soft aggregates represent the natural extraction of fine-grained material from the bottom sediments and contain very limited information about the provenance since clay minerals (illite and chlorite) and accessory minerals identified in the aggregates could be derived from a broad variety of rock types (igneous, metamorphic or sedimentary) disintegrated by ice erosion.

Relatively large rock clasts from 3582 and $3607 \mathrm{~m}$ depth are too heavy to be suspended or moved to the ice bottom by frazil ice crystals and so they were likely incorporated into accreted ice when it was grounded onto the shallow bottom in the south-western part of Lake Vostok. Subangular to semi-rounded shapes of the clasts suggests that they have been scraped off bedrock by the ice sheet and transported to the lake (Fig. 2) so that the bedrock upstream of south-western Lake Vostok is inferred to be composed of sedimentary rocks. This inference is confirmed by modeling of airborne magnetic and gravity data acquired by US expeditions which show that the area between Lake Vostok and the Vostok Subglacial Highlands is covered by thick nonmagnetic and low-density $\left(2.5 \mathrm{~g} / \mathrm{cm}^{3}\right)$ layer which is interpreted to be of sedimentary nature (Studinger et al., 2003). In the EA tectonic framework, these sedimentary strata can be considered as a part of the platform cover occupying the EA lowlands.

Age determinations of zircon and monazite identified in the quartzose siltstone give valuable information about the provenance of these minerals. Poor to moderate roundness of quartz and zircon grains probably testifies that the source of detritus was not very distant. Veevers (1994), based on paleocurrent directions within Gondwana, argued that at least from Early Permian time the Gamburtsev Mountains area was the upland. If so, an 
EA highland including the Gamburtsev Subglacial Mountains and the Vostok Subglacial Highlands (Fig. 1) is a potential source of terrigenous material including the zircons and monazites identified in the siltstone clasts. The ages of the detrital zircons clustered between 0.8 and $1.2 \mathrm{Ga}(\mathrm{n}=12)$ and between 1.6 and $1.8 \mathrm{Ga}(\mathrm{n}=4)$ suggest that the bedrock provenance is comparable to the tectonic provinces outcropped within the costal areas of EA (Fig. 1). The final tectonic event $(0.6-0.48 \mathrm{Ga})$ is represented by the single $\sim 600$ Ma zircon (Fig. 6).

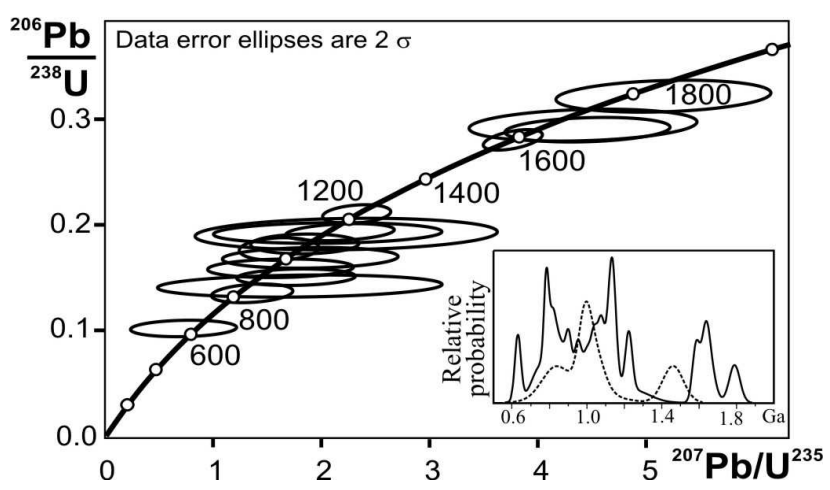

Figure 6. U-Pb concordia diagram for studied zircons. Inset: probability age distribution for zircons $\left({ }^{206} \mathrm{~Pb} /{ }^{238} \mathrm{U}\right.$; solid line) and monazites $\left({ }^{208} \mathrm{~Pb} \quad{ }^{232} \mathrm{Th}\right.$; dotted line). SHRIMP-II parameters and zircon standards: diameter of analytic spot is not more than $15 \mu \mathrm{m}$; primary ion beam is c. $3 \mathrm{nA}$; measurement duration (5 cycles) is $10-25 \mathrm{~min}$; zircon TEMORA of $417 \mathrm{Ma}$ old and Zircon SL13 with $238 \mathrm{ppm} \mathrm{U}$ content were used as age and $\mathrm{U}$ content standards, respectively.

\section{Summary}

Sediment inclusions extracted from cores of accreted ice above Lake Vostok represent mainly soft aggregates consisting of microparticles of clay-mica minerals, quartz with subangular to angular shape, and a variety of accessory minerals. Two of eight sampled inclusions are clasts of fine-grained cemented rocks. The largest of them (c. $4.7 \mathrm{~mm}$ long) consists of poorly-rounded quartz and a minor amount of accessories including zircon and monazite, and is classified as quartzose siltstone. We infer that the bedrock upstream (northwest) of Lake Vostok (from where the siltstone clast was scraped off bedrock by ice and transported to the lake) is of sedimentary nature. More than 20 zircon and monazite grains in the siltstone clast have yielded two age clusters ranging between 0.8 $1.2 \mathrm{Ga}$ and $1.6-1.8 \mathrm{Ga}$. These ages testify that their source land - Gamburtsev Subglacial Mountains and the Vostok Subglacial Highlands - is dominated by $1.6-1.8$ $\mathrm{Ga}$ (Paleoproterozoic) and 0.8 - 1.2 Ga (MesoproterozoicNeoproterozoic) assemblages.

Acknowledgments. We are grateful to John Veevers, Simon Harley.and Philip Kyle whose constructive comments were welcome and to Vladimir Lipenkov and Sergey Bulat for providing the inclusion samples. Funding for this work was provided by Russia Fund of Basic Research (grant 07-05-00736) and by Federal Target Program "World Ocean" (Subprogram "Antarctica", Project 4).

\section{References}

Fitzsimons, I. C. W. (2000), A review of tectonic events in the East Antarctic Shield, and their implications for Gondwana and earlier supercontinents, Jour. Afr. Earth Sciences, 31, 3-23.

Grikurov, G.E. (1980), Explanatory notes to Tectonic Map of Antarctica (Scale 1:1 000 000), NIIGA, Leningrad, 84.

Grikurov, G.E., G.L. Leitchenkov, E.N. Kamenev, E.V. Mikhalsky, A.V. Golinsky, V.N. Masolov, and A.A. Laiba (2003), Antarctic tectonic provinces, Arctic and Antarctic, Moscow, Nauka, 2 (36), 2647.

Jouzel, J., J.-R Petit, R. Souchez, et al. (1999), More than 200 meters of lake ice above subglacial lake Vostok, Antarctica. Science, 286, 21382141.

Kapitsa, A. P., J.K. Ridley, G.Q. Robin, M.J. Siegert, and I.A. Zotikov (1996), A large deep frashwater lake beneath the ice of central East Antarctica, Nature, 381, 684-686.

Leitchenkov, G.L., B.V. Belyatsky, A.M. Popkov, and S.V. Popov (2004), Geological nature of Subglacial Lake Vostok, East Antarctica. Data of glaciological studies, Moscow, 98, 81-92.

Lythe, M.B., D.G. Voughan, and BADMAP consortium (2000), BEDMAP - Bed topography of the Antarctic, 1: 10000000 Scale map. BAS (Misc) 9. Cambridge.

Royston-Bishop, G., J.C. Priscu, M. Tranter, B. Christner, M.J. Siegert, V. and Lee (2005), Incorporation of particulates into accreted ice above subglacial Lake Vostok, Antarctica, Annals of Glaciology, 40, 145-150.

Souchez, R., J.R. Petit, J. Jouzel, M. de Angelis and J.L. Tison (2003), Reassessing Lake Vostok's behavior from existing and new ice core data, Earth and Planet. Sci. Lett., 217 (1.2), 163-170.

Studinger, M., R. Bell, G.D. Karner, A.A Tikku, J.W. Holt, D.L Morse, T.G. Richter, S.D. Kempf, M.E. Peters, and D.D. Blankenship, R.E. Sweeney, and V.L. Rystrom (2003), Ice cover, landscape setting and geological framework of Lake Vostok, East Antarctica, Earth Planet. Sci. Lett., 205, 195-210.

Veevers, J.J. (1994), Case for the Gamburtsev Subglacial Mountains of East Antarctica originating by mid-Carboniferous shortening of an intracratonic basin, Geology 22, 593-596. 